\title{
KEBIJAKAN FORMULASI HUKUM PIDANA DALAM PENANGGULANGAN TINDAK PIDANA KORUPSI
}

\begin{abstract}
Ridwan $^{1}$
ABSTRAK

Sebagai negara yang berdaulat, Indonesia memiliki cita-cita yang mulia yaitu menciptakan kesejahteraan umum yang merupakan landasan utama bagi setiap pengambilan kebijakan, termasuk kebijakan legislatif untuk terus berupaya meningkatkan taraf kehidupan masyarakat yang merupakan hak konstitusional setiap warga negara Indonesia. Namun demikian, cita-cita tersebut dapat terhambat oleh tindakan korupsi yang berkembang sangat cepat, bahkan merusak sendi-sendi kehidupan bangsa, dan tidak hanya merugikan keuangan atau perekonomian negara, tetapi merusak perekonomian rakyat, serta menjadi ancaman bagi stabilitas Nasional dan internasional. Untuk itu diperlukan kebijakan formulasi hukum pidana khususnya mengenai formulasi tindak pidana, karena itu permasalahan difokuskan pada dua hal pokok yaitu bagaimana kebijakan formulasi tindak pidana korupsi dalam perundang-undangan yang berlaku saat ini dan yang akan datang. Tujuan penelitian adalah menganalisa kebijakan formulasi yang berkaitan dengan pemberantasan tindak pidana korupsi saat ini serta untuk mengetahui dan menganalisa mengenai kebijakan formulasi yang harus dilakukan dalam rangka penanggulangan tindak pidana korupsi yang akan datang. Penelitian ini menggunakan metode yuridis normatif, dengan mengkonsepsikan hukum sebagai kaidah norma yang merupakan patokan prilaku manusia, dengan menekankan pada sumber data sekunder yang dikumpulkan dari sumber primer yaitu perundangundangan. Berdasarkan hasil penelitian bahwa kebijakan formulasi hukum pidana dalam penanggulangan tindak pidana korupsi masih terdapat beberapa kelemahan, sehingga diperlukan pembaharuan dengan menekankan rumusan tindak pidana pada unsur"merugikan negara". Mengingat perkembangan korupsi semakin cepat dari tahun ke tahun, maka Konsep KUHP dirasakan sebagai kebijakan hukum pidana yang tepat bagi penanggulangan tindak pidana korupsi yang akan datang.
\end{abstract}

Kata kunci : kebijakan formulasi, Penanggulangan, tindak pidana korupsi

\footnotetext{
${ }^{1}$ Dosen Fakultas Hukum Universtas Sultan Ageng Tirtayasa Banten
} 


\section{A. PENDAHULUAN}

\section{A.1. Latar Belakang}

Terbentuknya negara Indonesia tidak lain memiliki suatu tujuan yang mulia yaitu mendorong dan menciptakan kesejahteraan umum dalam payung Negara Kesatuan Republik Indonesia yang berlandaskan Pancasila.Tujuan atau cita-cita tersebut tercermin dalam pembukaan Undang-undang Dasar Negara Republik Indonesia Tahun 1945 dalam alinea ke-4 (empat), yaitu melindungi segenap bangsa Indonesia dan seluruh tumpah darah Indonesia dan untuk memajukan kesejahteraan umum. Untuk mewujudkan cita-cita luhur tersebut, yang berkaitan dengan manifestasi atas kesejahteraan seluruh rakyat Indonesia maka lahirlah suatu pedoman bagi Penyelenggaraan Negara yang Bersih dan Bebas Korupsi, Kolusi, dan Nepotisme yang dirumuskan dalam Undang-Undang Nomor 28 Tahun 1999. Dalam undang-undang tersebut memuat prinsip-prinsip atau asas-asas Kepastian hukum, Tertib Penyelenggaraan Negara, Kepentingan Umum , Keterbukaan, Proporsionalitas, Profesionalitas, dan Akuntabilitas.

Tindak pidana korupsi merupakan perbuatan yang bukan saja dapat merugikan keuangan negara akan tetapi juga dapat menimbulkan kerugian-kerugian pada perekonomian rakyat. Barda Nawawi Arief berpendapat bahwa, tindak pidana korupsi merupakan perbuatan yang sangat tercela, terkutuk dan sangat dibenci oleh sebagian besar masyarakat; tidak hanya oleh masyarakat dan bangsa Indonesia tetapi juga oleh masyarakat bangsa-bangsa di dunia. ${ }^{2}$

Perkembangan korupsi di Indonesia masih tergolong tinggi, sementara pemberantasannya masih sangat lamban, Romli Atmasasmita, menyatakan bahwa, Korupsi di Indonesia sudah merupakan virus flu yang menyebar ke seluruh tubuh pemerintahan sejak tahun 1960an langkah-langkah pemberantasannya pun masih tersendat-sendat sampai sekarang. ${ }^{3}$ Kondisi ini tampaknya sangat sesuai dengan semangat pembentuk undang-undang, yaitu melalui kebijakan legislatif dengan menetapkan undang-undang nomor 31 tahun 1999 sebagaimana yang telah diperbaharui dengan undang-undang nomor 20 tahun 2001 tentang Pemberantasan Tindak pidana Korupsi yang di dalamnya mencantumkan sifat melawan hukum secara materiel. Hal ini sebagaimana dirumuskan dalam penjelasan umum yang menegaskan bahwa, agar dapat menjangkau berbagai modus operandi penyimpangan keuangan negara atau perekonomian negara yang semakin canggih dan rumit, maka tindak pidana yang diatur dalam undang-undang ini dirumuskan sedemikian rupa sehingga meliputi perbuatan-perbuatan memperkaya diri sendiri atau orang lain atau suatu korporasi secara "melawan hukum" dalam pengertian formil dan materil. Namun demikian kesadaran akan pentingnya penetapan sifat melawan hukum materiel tersebut harus kandas melalui putusan Mahkamah Konstitusi Nomor 003/PUU/2006, yang menyatakan bahwa sifat melawan hukum materiel bertentangan dengan Pasal 28D ayat (1) Undang-Undang Dasar Negara Republik Indonesia 1945, sehingga sifat melawan hukum materiel dianggap tidak mempunyai kekuatan hukum yang mengikat, di samping persoalan mengenai putusan Mahkamah Konstitusi tersebut, rumusan mengenai tindak pidana korupsi juga masih bersifat parsial dan tersebar di beberapa undang-undang, sementara pemberatan sanksi seperti hukuman mati hanya ditujukan pada keadaan tertentu. ${ }^{4}$ Dengan adanya persoalan-persoalan tersebut di atas, perlu difikirkan

\footnotetext{
${ }^{2}$ Muladi dan Barda Nawawi Arief, Bunga Rampai Hukum Pidana, Bandung, Alumni, 1992:133

${ }^{3}$ Romli Atmasasmita, Sekitar Masalah Korupsi,Aspek Nasional dan Aspek Internasional, Bandung, Mandar Maju, $2004: 1$

${ }^{4}$ Lihat penjelasan Pasal 2 ayat (2) Undang-undang Nomor 20 Tahun 2001 Tentang Pemberantasan Tindak Pidana Korupsi, dalam penjelasan tersebut ditegaskan bahwa 
kebijakan formulasi hukum pidana dalam rangka penanggulangan tindak pidana korupsi.

\section{A.2. Rumusan Masalah}

Bertitik tolak pada latar belakang yang dikemukakan di atas, maka permasalahan pokok dalam penelitian ini adalah berkisar pada masalah kebijakan formulasi hukum pidana, khususnya terhadap aspek substansi mengenai perumusan tindak pidana korupsi dalam sistem perundang-undangan di Indonesia. Adapun rumusan permasalahannya adalah sebagai berikut :

1. Bagaimana kebijakan formulasi tindak pidana korupsi dalam perundang-undangan yang berlaku saat ini?

2. Bagaimana Kebijakan formulasi tindak pidana korupsi yang akan datang ?

\section{A.3. Tujuan Penelitian}

Berdasarkan uraian pada latar belakang penelitian di atas, maka sebagai tujuan dilakukan penelitian ini adalah :

1. Menganalisa kebijakan formulasi yang berkaitan dengan pemberantasan tindak pidana korupsi saat ini.

2. Untuk mengetahui dan menganalisa mengenai kebijakan formulasi yang harus dilakukan dalam rangka penanggulangan tindak pidana korupsi di masa yang akan datang.

\section{A.4. Tinjaun Pustaka}

Upaya penanggulangan tindak pidana korupsi, khususnya pada aspek substansi merupakan langkah yang sangat penting dan strategis, ini berarti penanggulangan tindak pidana korupsi harus dimulai dari kebijakan formulasi guna melakukan pembaharuan hukum pidana. Mengenai kebijakan formulasi dalam penanggulangan kejahatan (termasuk tindak pidana korupsi) menurut Barda Nawawi Arief bahwa, dilihat dari sudut pendekatan kebijakan, maka pembaharuan hukum pidana memiliki makna :

a. Sebagai bagian dari kebijakan sosial, pembaharuan hukum pidana pada hakikatnya merupakan bagian dari upaya untuk mengatasi masalah-masalah sosial, dalam rangka mencapai/menunjang tujuan nasional (kesejahteraan masyarakat dan sebagainya);

b. Sebagai bagian dari kebijakan kriminal, pembaharuan hukum pidana pada hakikatnya merupakan bagian dari upaya perlindungan masyarakat (khususnya upaya penanggulangan kejahatan);

c. Sebagai bagian dari kebijakan penegakan hukum, pembaharuan hukum pidana pada hakikatnya merupakan bagian dari upaya memperbaharui substansi hukum (legal substance) dalam rangka lebih mengefektifkan penegakan hukum. ${ }^{5}$

Menurut Barda Nawawi Arief, usaha penanggulangan dengan hukum pidana pada hakikatnya merupakan bagian dari usaha penegakan hukum (khususnya penegakan hukum pidana). Oleh karena itu sering pula dikatakan bahwa politik hukum atau kebijakan hukum pidana merupakan bagian dari kebijakan penegakan

dimaksudkan sebagai pemberatan bagi pelaku tindak pidana korupsi apabila tindak pidana tersebut dilakukan pada waktu negara dalam keadaan bahaya sesuai dengan undang-undang yang berlaku, pada waktu terjadi bencana nasional, sebagai pengulangan tindak pidana korupsi atau pada waktu negara dalam keadaan krisis ekonomi dan moneter.

5 Barda Nawawi Arief, Masalah Penegakan Hukum dan Kebijakan Hukum Pidana dalam Penanggulangan Kejahatan, Jakarta,Kencana 2008 : 26 
hukum (law enforcement policy). ${ }^{6}$ Secara sistem kebijakan hukum pidana dari aspek formulasi merupakan tahap yang strategis. Hal ini sebagaimana dikatakan oleh Barda Nawawi Arief, proses legislasi/formulasi/pembuatan peraturan perundangundangan pada hakikatnya merupakan proses penegakan hukum "in abstracto". Proses legislasi /formulasi ini merupakan tahap awal yang sangat strategis dari proses penegakan hukum"in concreto". Oleh karena itu kesalahan/kelemahan pada tahap kebijakan legislasi/formulasi merupakan kesalahan strategis yang dapat menjadi penghambat upaya penegakan hukum "in concreto"7. Penegakan hukum itu sendiri menurut Nyoman Serikat Putra Jaya dapat diartikan sebagai "perhatian dan penggarapan", baik perbuatan-perbuatan melawan hukum yang sungguh-sungguh terjadi (onrecht in actu) maupun perbuatan melawan hukum yang mungkin akan terjadi (onrecht in potentie). Dengan demikian, di sini penegakan hukum tidak hanya diartikan sebagai penerapan hukum positif, tetapi juga penciptaan hukum positif. ${ }^{8} \mathrm{Hal}$ ini berarti juga bahwa kebijakan hukum pidana atau penal policy merupakan bagian dari kebijakan penegakan hukum pidana. Dalam melakukan pembaharuan tersebut, tentu harus dilihat masalah pokok hukum pidana yaitu "tindak pidana" (strafbaarfeit/criminal act/actus rebus), "kesalahan" (schuld/guit/mens rea), dan "pidana" (straf/punishment/poena). ${ }^{9}$ Namun dalam tulisan ini penekanan pembaharuan itu lebih dikhususkan lagi yaitu pada "tindak pidana"nya saja.

Dasar patut dipidananya perbuatan, berkaitan erat dengan masalah sumber hukum atau landasan legalitas untuk menyatakan suatu perbuatan sebagai tindak pidana atau bukan. ${ }^{10}$ Tindak pidana tersebut dalam KUHP tidak dirumuskan secara tegas tetapi hanya menyebutkan unsur-unsur tindak pidananya saja, tetapi dalam konsep hal tersebut telah dirumuskan atau diformulasikan, misalnya dalam konsep KUHP dirumuskan dalam Pasal 11 yang menyatakan bahwa:

(1) Tindak pidana adalah perbuatan melakukan atau tidak melakukan sesuatu yang oleh peraturan perundang-undangan dinyatakan sebagai perbuatan yang dilarang dan diancam dengan pidana.

(2) Untuk dinyatakan sebagai tindak pidana, selain perbuatan tersebut dilarang dan diancam pidana oleh peraturan perundang-undangan, harus juga bersifat melawan hukum atau bertentangan dengan kesadaran hukum masyarakat.

(3) Setiap tindak pidana selalu dipandang bersifat melawan hukum, kecuali ada alasan pembenar.

Penempatan kesadaran hukum masyarakat sebagai salah satu sifat melawan hukum, yaitu hukum tak tertulis merupakan jembatan hukum agar penggunaan hukum pidana dalam penanggulangan kejahatan dapat menjangkau keadilan substantif atau keadilan materil, terlebih hal tersebut jika dikaitkan dengan tindak pidana korupsi, di mana korupsi merupakan hal yang sangat dicela oleh masyarakat. Penempatan sifat melawan hukum materiel tersebut juga untuk menjangkau keseimbangan dalam kehidupan masyarakat, karena menurut Muladi tindak pidana merupakan gangguan terhadap keseimbangan, keselarasan dan keserasian dalam kehidupan masyarakat yang mengakibatkan gangguan individual ataupun

\footnotetext{
${ }^{6}$ Barda Nawawi Arief, Bunga Rampai Kebijakan Hukum Pidana, Perkembangan Penyusunan Konsep KUHP Baru, Jakarta, Kencana, $2008: 24$

${ }^{7}$ Barda Nawawi Arief, op.cit. 2008: 25

${ }^{8}$ Nyoman Serikat Putra Jaya, Beberapa Pemikiran ke Arah Pengembangan Hukum Pidana, Bandung, Citra Aditya Bakti,2008:52

${ }^{9}$ Barda Nawawi Arief, Tujuan dan Pedoman pemidanaan, Semarang, Bandan Penerbit Undip 2009:5 ${ }^{10}$ Barda Nawawi Arief, Perkembangan Sistem Pemidanaan di Indonesia, Semarang, Badan Penerbit Undip, 2009:49
} 
masyarakat. ${ }^{11}$ Berdasarkan kajian etimologis tindak pidana berasal dari kata "strafbaar feit" di mana arti kata ini menurut Simons adalah kelakuan (handeling) yang diancam dengan pidana, yang bersifat melawan hukum, yang berhubungan dengan kesalahan dan yang dilakukan oleh orang yang mampu bertanggung jawab. ${ }^{12}$ Rumusan tersebut menurut Jonkers dan Utrecht merupakan rumusan yang lengkap, yang meliputi : diancam dengan pidana oleh hukum, bertentangan dengan hukum, dilakukan oleh orang yang bersalah, orang itu dipandang bertanggung jawab atas perbuatannya. ${ }^{13}$ Selain pengertian tindak pidana sebagaimana diuraikan di atas, ilmu hukum pidana juga mengenal istilah percobaan. terdapat dua pandangan ahli pikir hukum pidana mengenai percobaan yaitu:

1. Percobaan dipandang sebagai Straufausdehnungsgrund (dasar/alasan memperluas dapat dipidananya orang), yaitu seseorang yang melakukan percobaan untuk melakukan suatu tindak pidana meskipun tindak memenuhi semua unsur delik, tetap dipidana apabila telah memenuhi rumusan Pasal 53 KUHP, termasuk dalam pandangan ini adalah Hazewinkel-Suringa dan Oemar Senoadji.

2. Percobaan dipandang sebagai Tatbestandausdehnungsgrund (dasar/alasan memperluas dapat dipidananya perbuatan), yaitu percobaan melakukan suatu tindak pidana merupakan suatu kesatuan yang bulat dan lengkap, tetapi merupakandelik yang sempurna hanya dalam bentuk yang khusus/istimewa. Jadi merupakan delik tersendiri (delictum sui generis). ${ }^{14}$

Tentang percobaan itu sendiri dirumuskan dalam Pasal 53 ayat (1) KUHP, " mencoba melakukan kejahatan dipidana, jika niat untuk itu telah ternyata dari adanya permulaan pelaksanaan, dan tidak selesainya pelaksanaan itu, bukan semata-mata disebabkan karena kehendaknya sendiri". ${ }^{15}$ Penekanan dalam Pasal 53 tersebut adalah percobaan tersebut dapat dipidana dalam hal percobaan terhadap kejahatan bukan percobaan dalam hal pelanggaran, dan berdasarkan Pasal 54 KUHP bahwa "mencoba melakukan pelanggaran tidak dipidana. ${ }^{16}$ Perihal pengertian tindak pidana dan percobaan dalam kaitannya antara KUHP dan Undangundang Khusus di luar KUHP, yang dalam hal ini adalah Undang-undang mengenai pemberantasan tindak pidana korupsi sebagaimana yang diatur dalam UndangUndang Nomor 31 Tahun 1999 jo. Undang-undang Nomor 20 Tahun 2001 menjadi penting, karena keduanya merupakan kesatuan sistem hukum pidana. ${ }^{17}$ Sebagai suatu sistem, maka dalam perundang-undangan khusus perlu menyebutkan atau menentukan kualifikasi tindak pidana sebagai "kejahatan" atau "pelanggaran" , sehingga secara yuridis tidak menimbulkan masalah untuk memberlakukan aturan umum KUHP yang tidak secara khusus diatur dalam Undang-undang khusus di luar KUHP, ${ }^{18}$ karena berdasarkan aturan induk (KUHP) hanya percobaan terhadap kejahatan saja yang dapat dipertanggungjawabkan. Di sisi lain perlu juga dijabarkan secara yuridis mengenai istilah-istilah tertentu yang merupakan tindak pidana seperti "permufakatan jahat", hal ini untuk mempermudah operasionalisasi KUHP dalam menjembatani aturan-aturan umum yang tidak diatur dalam perundang-undangan

\footnotetext{
${ }^{11}$ Muladi, Lembaga Pidana Bersyarat, Bandung, Alumni, 2002:61

${ }^{12}$ Moeljatno, Asas-asas Hukum Pidana, Jakarta, Rineka Cipta, 2000:56

${ }^{13}$ Andi Hamzah, Asas-asas Hukum Pidana, Jakarta, Rineka Cipta, 2008:88

${ }^{14}$ Barda Nawawi Arief, Sari Kuliah Hukum Pidana Lanjut,Semarang, Badan Penerbit Undip, 2008:2

${ }^{15}$ Moeljatno, KUHP, Jakarta, Bumi Aksara, 1999:24

${ }^{16}$ Ibid. hlm. 25

${ }^{17}$ Lihat Barda Nawawi Arief, RUU KUHP Baru Sebuah Restrukturisasi/Rekonstruksi Sistem Hukum Pidana Indonesia, Semarang, Badan Penerbit Undip, 2008:3

${ }^{18}$ Ibid. hlm. 7
} 
yang bersifat khusus. Menurut Barda Nawawi Arief, "permufakatan jahat" merupakan istilah yuridis sama halnya dengan istilah yuridis lainnya seperti "percobaan" "pembantuan","pengulangan" ${ }^{19}$ lebih lanjut Barda Nawawi Arief menjelaskan bahwa di Belanda apabila undang-undang khusus di luar KUHP menyatakan bahwa "permufakatan jahat" dapat dipidana, maka undang-undang khusus tersebut membuat pengertian mengenai "permufakatan jahat" di dalam "ketentuan umum" nya. ${ }^{20}$ Jadi perumusan pengertian mengenai istilah-istilah yuridis dalam undang-undang khusus mengenai tindak pidana korupsi merupakan hal yang sudah semestinya dilakukan agar terjadi sinkronisasi antara undang-undang khusus dengan KUHP sebagai sistem induk.

Mengenai pengertian korupsi pada hakikatnya memiliki dimensi yang luas, oleh karena itu perlu penjabaran secara etimologis maupun secara yuridis dan mensinergikannya dengan pandangan para pakar mengenai apa yang dimaksud dengan korupsi. Berdasarkan Black's Law Dictionary, korupsi adalah perbuatan yang dilakukan dengan maksud untuk memberikan suatu keuntungan yang tidak resmi dengan hak-hak dari pihak lain secara salah menggunakan jabatannya atau karakternya untuk mendapatkan suatu keuntungan untuk dirinya sendiri. Mengenai istilah Korupsi itu sendiri, menurut Sudarto bermula bersifat umum dan baru menjadi istilah hukum untuk pertama kalinya dalam Peraturan Penguasa Militer Nomor PRT/PM/06/1957 Tentang Pemberantasan Korupsi. ${ }^{21}$ Dalam konsideran Peraturan Penguasa Militer tersebut dikatakan "bahwa berhubung tidak adanya kelancaran dalam usaha-usaha memberantas perbuatan-perbuatan yang merugikan keuangan dan perekonomian negara yang oleh khalayak ramai dinamakan korupsi, perlu segera menetapkan suatu tata kerja untuk dapat menerobos kemacetan dalam usaha-usaha memberantas korupsi". Untuk menangkal kejahatan korupsi sebagai kejahatan yang berbahaya bagi kehidupan sosial, diperlukan sebuah perubahan kultur, melalui sebuah perubahan atau penataan kembali pada sistem hukum pidana yang mengatur mengenai tindak pidana korupsi, yang diharapkan mampu mempengaruhi sikap tindak bangsa Indonesia tanpa kecuali. Perubahan kultur melalui penataan hukum tersebut oleh Soerjono Soekanto dinamakan sebagai social engineering atau social planing yaitu cara-cara untuk mempengaruhi masyarakat dengan sistem yang teratur dan direncanakan terlebih dahulu. ${ }^{22}$ Untuk itulah maka diperlukan upaya-upaya melalui penal policy. Menurut Marc Ancel, penal policy adalah suatu ilmu sekaligus seni yang pada akhirnya mempunyai tujuan praktis untuk memungkinkan peraturan hukum positif dirumuskan secara lebih baik dan untuk memberi pedoman tidak hanya kepada pembuat undang-undang, tetapi juga kepada pengadilan yang menerapkan undang-undang dan juga kepada para penyelenggara atau pelaksana putusan pengadilan. ${ }^{23}$

\section{A.5. Metode Penelitian}

Istilah "metododologi" berasal dari kata "metode" yang berarti "jalan ke". ${ }^{24}$ Menurut Sunaryati Hartono, metode penelitian adalah cara atau jalan atau proses pemeriksaan atau penyelidikan yang menggunakan cara penalaran dan berfikir yang logis-analitis (logika), berdasarkan dalil-dalil, rumus-rumus dan teori-teori suatu ilmu (atau beberapa cabang ilmu) tertentu, untuk menguji kebenaran (atau mengadakan verifikasi) suatu hipotesis atau teori tentang gejala-gejala atau peristiwa alamiah,

\footnotetext{
${ }^{19}$ Ibid.hlm 9

${ }^{20}$ ibid

${ }^{21}$ Sudarto, Hukum dan Hukum Pidana,Bandung, Alumni, 1977:123

${ }^{22}$ Soerjono Soekanto, Pokok-pokok Sosiologi Hukum, Jakarta, RadjaGrafindo Persada, 2002:107

${ }^{23}$ Barda Nawawi Arief, op.cit. 2008:19

${ }^{24}$ Soerjono Soekanto, Pengantar Penelitian Hukum, Jakarta, UI-Press, $1986: 5$
} 
peristiwa sosial atau peristiwa hukum yang tertentu. ${ }^{25}$ Sejalan dengan pengertian metode ilmiah sebagaimana tersebut di atas, maka dalam penelitian ini peneliti menggunakan metode yuridis normatif, dengan mengkonsepsikan hukum sebagai kaidah norma yang merupakan patokan prilaku manusia, dengan menekankan pada sumber data sekunder. ${ }^{26}$ Data sekunder yang digunakan dalam penelitian ini dikumpulkan dari sumber primer berupa perundang-undangan. ${ }^{27}$

Bertolak dari pengertian metode penelitian di atas, maka dalam menggambarkan atau mendeskripsikan metode penelitian yang digunakan dalam penelitian ini, penulis lebih menekankan pada penjelasan mengenai pendekatan penulis terhadap permasalahan yang diteliti. Berdasarkan perumusan masalah dan tujuan penelitian, dapat diidentifikasi bahwa permasalahan pokok dalam penelitian ini termasuk salah satu kebijakan hukum pidana, khususnya kebijakan formulasi di dalam merumuskan tindak pidana korupsi. Oleh karena itu pendekatan yang digunakan adalah pendekatan yang berorientasi pada kebijakan (policy-oriented approach). Namun karena sasaran utama dalam penelitian ini pada masalah kebijakan legislatif yaitu mengenai perundang-undangan dalam menetapkan dan merumuskan tindak pidana korupsi, maka pendekatannya terutama ditempuh lewat pendekatan yuridis normatif yang bertumpu pada data sekunder dan ditunjang dengan pendekatan yuridis historis dan yuridis komparatif, sebagai unsur penunjang. Analisasi data dilakukan secara kualitatif.

\section{B. HASIL PENELITIAN DAN PEMBAHASAN \\ B.1. Kebijakan Formulasi Hukum Pidana dalam Penanggulangan Tindak Pidana Korupsi saat ini}

Tindak pidana korupsi sebagaimana yang dirumuskan dalam undang-undang Nomor 31 Tahun 1999 jo, Undang-undang Nomor 20 Tahun 2001, terdapat beberapa ruang lingkup korupsi, dan menurut Hendarman Supandji ruang lingkup tersebut terbagi dalam 5 (lima) kelompok yaitu :

1. Kelompok delik yang berkaitan dengan kerugian keuangan negara.

2. Kelompok delik yang berkaitan dengan suap menyuap dan gratifikasi.

3. Kelompok delik yang terkait dengan penggelapan dalam jabatan.

4. Kelompok delik yang terkait dengan pemerasan dalam jabatan.

5. Kelompok delik yang terkait dengan pemborongan, leveransir dan rekanan. ${ }^{28}$

Ruang lingkup tindak pidana korupsi yang cukup luas, sebagaimana diatur dalam Nomor 31 Tahun 1999 jo. Undang-undang Nomor 20 Tahun 2001, pada hakikatnya sudah cukup baik. Namun demikian Undang-undang tersebut, masih terdapat persoalan-persoalan yuridis dalam merumuskan tindak pidana korupsi, di mana persoalan-persoalan tersebut dapat mengakibatkan sulitnya operasionalisasi KUHP sebagai sistem induk dalam menjembatani pemberantasan Tindak pidana Korupsi. Persoalan-persoalan tersebut adalah sebagai berikut:

1. Undang-undang Nomor 31 Tahun 1999 jo Undang-undang Nomor 20 Tahun 2001 Tentang Tindak Pidana Korupsi belum merumuskan batasan-batasan

\footnotetext{
${ }^{25}$ Sunaryati Hartono, Penelitian Hukum di Indonesia Pada Akhir Abad ke- 20, Bandung, Alumni, 1994 : 105

${ }^{26}$ Amirudin \& Zainal Asikin, Pengantar Metode Penelitian Hukum, Jakarta, RadjaGrafindo Persada, 2004:118.

${ }^{27}$ Ronny Hanitijo Soemitro, Metodologi Penelitian Hukum, Ghalia Indonesia, 1982, hal.

${ }^{28}$ Hendarman Supandji, "Peningkatan Pencegahan Tindak Pidana Korupsi dalam Pelaksanaan Tugas Kejaksaan", Makalah disampaikan dalam Kuliah Umum di Undip Semarang, tanggal 27 Februari 2009. hlm. 5
} 
yuridis atau pengertian yuridis mengenai tindak pidana korupsi dalam hal permufakatan jahat, sedangkan permufakatan jahat yang terdapat dalam KUHP Pasal 88 merupakan istilah yang diatur dalam Bab IX yang tidak mungkin dioperasionalkan mengingat Pasal 103 KUHP mensyaratkan bahwa ketentuanketentuan dalam Bab I sampai Bab VIII berlaku bagi perbuatan-perbuatan yang oleh ketentuan perundang-undangan lainnya diancam dengan pidana. Demikian juga mengenai istilah "pembantuan" yang merupakan istilah yuridis, belum diatur dalam undang-undang ini.

2. Undang-undang Nomor 31 Tahun 1999 jo Undang-undang Nomor 20 Tahun 2001 Tentang Tindak Pidana Korupsi tidak mencantumkan kualifikasi delik apakah sebagai "pelanggaran" atau "kejahatan" sehingga KUHP tidak dapat dioperasionalkan terhadap tindak pidana korupsi

Selain persoalan -persoalan yuridis sebagaimana diuraikan di atas, juga terdapat persoalan-persoalan mengenai lingkup tindak pidana korupsi yang tersebar dalam perundang-undangan lain di luar Undang-undang Nomor 31 Tahun 1999 jo. Undang-undang Nomor 20 Tahun 2001 Tentang Pemberantasan Tindak Pidana Korupsi, yaitu :

1. Undang-undang tentang perbankan.

Rumusan mengenai tindak pidana dalam Undang-Undang Nomor 10 Tahun 1998 Tentang Perbankan terdapat dalam Pasal 49 ayat (2) yang menyatakan bahwa"

Anggota Dewan Komisaris, Direksi, atau pegawai bank yang dengan sengaja :

a. meminta atau menerima, mengizinkan atau menyetujui untuk menerima suatu imbalan, komisi, uang tambahan, pelayanan, uang atau barang berharga, untuk keuntungan pribadinya atau untuk keuntungan keluarganya, dalam rangka mendapatkan atau berusaha mendapatkan bagi orang lain dalam memperoleh uang muka, bank garansi, atau fasilitas kredit dari bank, atau dalam rangka pembelian atau pendiskontoan oleh bank atas surat-surat wesel, surat promes, cek, dan kertas dagang atau bukti kewajiban lainnya, ataupun dalam rangka memberikan persetujuan bagi orang lain untuk melaksanakan penarikan dana yang melebihi batas kreditnya pada bank ;

Rumusan Pasal 49 ayat (2) huruf a tersebut menyatakan bahwa anggota dewan komisaris, direksi, atau pegawai bank yang "meminta atau menerima, mengizinkan atau menyetujui untuk menerima suatu imbalan, komisi, uang tambahan, pelayanan, uang atau barang berharga, untuk keuntungan pribadinya atau untuk keuntungan keluarganya". Jika ditelaah lebih teliti, rumusan tersebut merupakan rumusan tindak pidana korupsi dalam lingkup suap, atau gratifikasi sebagaimana tercantum dalam undang-undang tindak pidana korupsi.

2. Undang-undang mengenai pajak

Rumusan tindak pidana dalam lingkungan perpajakan dituangkan dalam Pasal 36A undang-undang Nomor 16 Tahun 2000 ditegaskan bahwa “

"Apabila petugas pajak dalam menghitung atau menetapkan pajak tidak sesuai dengan Undang-undang perpajakan yang berlaku sehingga merugikan negara, maka petugas pajak yang bersangkutan dapat dikenakan sanksi sesuai dengan ketentuan peraturan perundang-undangan yang berlaku."Penjelasan Pasal 36A undang-undang Nomor 16 Tahun 2000 tersebut, menyatakan bahwa:

"Dalam rangka meningkatkan pelayanan kepada Wajib Pajak dan meningkatkan kemampuan petugas pajak maka terhadap petugas pajak yang menghitung atau menetapkan pajak yang tidak sesuai dengan Undangundang perpajakan yang berlaku sehingga menimbulkan kerugian negara, 
dikenakan sanksi sesuai dengan ketentuan peraturan perundang-undangan yang berlaku"

Rumusan sebagaimana yang dituangkan dalam Pasal 36A Undang-undang Nomor 16 Tahun 2000 tersebut, identik dengan rumusan tindak pidana korupsi, di mana unsur yang disebutkan adalah "merugikan negara", dan unsur "merugikan negara" yang dimaksud dalam rumusan pasal tersebut adalah merugikan negara dalam hal "keuangan atau perekonomian negara", hal ini didasarkan atas lingkup penanganan pajak adalah bagian dari departemen keuangan atau membidangi keuangan dan perekonomian negara.Seiring perkembangan dan kebutuhan masyarakat, maka undang-undang Nomor 16 Tahun 2000 Tentang Pajak tersebut diubah dengan Undang-undang Nomor 28 Tahun 2007. Dalam undang-undang ini Pasal 36A mengalami perubahan sebagai berikut:

(1) Pegawai pajak yang karena kelalaiannya atau dengan sengaja menghitung atau menetapkan pajak tidak sesuai dengan ketentuan undang-undang perpajakan dikenai sanksi sesuai dengan ketentuan peraturan perundangundangan.

(2) Pegawai pajak yang dalam melakukan tugasnya dengan sengaja bertindak di luar kewenangannya yang diatur dalam ketentuan peraturan perundangundangan perpajakan, dapat diadukan ke unit internal Departemen Keuangan yang berwenang melakukan pemeriksaan dan investigasi dan apabila terbukti melakukannya dikenai sanksi sesuai dengan ketentuan peraturan perundang-undangan.

(3) Pegawai pajak yang dalam melakukan tugasnya terbukti melakukan pemerasan dan pengancaman kepada Wajib Pajak untuk menguntungkan diri sendiri secara melawan hukum diancam dengan pidana sebagaimana dimaksud dalam Pasal 368 Kitab Undang- Undang Hukum Pidana.

(4) Pegawai pajak yang dengan maksud menguntungkan diri sendiri secara melawan hukum dengan menyalahgunakan kekuasaannya memaksa seseorang untuk memberikan sesuatu, untuk membayar atau menerima pembayaran, atau untuk mengerjakan sesuatu bagi dirinya sendiri, diancam dengan pidana sebagaimana dimaksud dalam Pasal 12 Undang-Undang Nomor 31 Tahun 1999 tentang Pemberantasan Tindak Pidana Korupsi dan perubahannya.

Perubahan dalam Pasal 36A Undang-undang Nomor 28 Tahun 2007, hanya menegaskan bahwa hanya ayat (4) yang merupakan tindak pidana korupsi, sehingga berlaku Pasal 12 Undang-undang Nomr 31 Tahun 1999 jo. Undangundang Nomor 20 Tahun 2001, di mana dalam undang-undang ini tindakan tersebut merupakan tindak pidana pemerasan dalam jabatan yang diatur dalam Pasal 12 huruf (e) yang menegaskan bahwa: "pegawai negeri atau penyelenggara negara yang dengan maksud menguntungkan diri sendiri atau orang lain secara melawan hukum, atau dengan menyalahgunakan kekuasaannya memaksa seseorang memberikan sesuatu, membayar, atau menerima pembayaran dengan potongan, atau untuk mengerjakan sesuatu bagi dirinya sendiri". Sangat disayangkan bahwa Pasal 36A ayat (1) tidak ditegaskan sebagai tindak pidana korupsi, padahal unsur "kelalaian" atau "kesengajaan" dalam penghitungan pajak dapat mengakibatkan kerugian pada "keuangan atau perekonomian negara", yang merupakan tindak pidana korupsi. Seyogyanya Pasal 36A ayat (1) Undangundang Nomor 28 Tahun 2007 tersebut tetap mempertahankan rumusan Pasal 36A Undang-undang Nomor 16 Tahun 2000, di mana unsur "merugikan negara" menjadi unsur esensial, hal ini dimaksudkan untuk menghindari multi tafsir 
terhadap rumusan tersebut, sehingga dapat dihindari pertentangan pemikiran mengenai dapat atau tidaknya diberlakukan sanksi sesuai Undang-undang Nomor 31 Tahun 1999 jo Undang-undang Nomor 20 Tahun 2001, walaupun pada hakikatnya undang-undang pemberantasan tindak pidana korupsi sebagaimana dimaksud dapat diberlakukan bagi pelanggaran perpajakan sesuai Pasal 36A ayat (1) Undang-undang Nomor 28 Tahun 2007, di mana Pasal 14 Undang-undang Nomor 31 Tahun 1999 jo. Undang-undang nomor 20 Tahun 2001, menegaskan bahwa "Setiap orang yang melanggar ketentuan Undang-undang yang secara tegas menyatakan bahwa pelanggaran terhadap ketentuan Undang-undang tersebut sebagai tindak pidana korupsi berlaku ketentuan yang diatur dalam Undang-undang ini".

3. Undang-undang tindak pidana pencucian uang

Pengaturan tindak pidana juga dirumuskan dalam Undang-undang Nomor 15 Tahun 2002 jo Undang-undang Nomor 25 Tahun 2003 Tentang Tindak Pidana Pencucian Uang, yaitu dalam Pasal 2 dirumuskan "Hasil tindak pidana adalah Harta Kekayaan yang berjumlah Rp500.000.000,00 (lima ratus juta rupiah) atau lebih atau nilai yang setara, yang diperoleh secara langsung atau tidak langsung dari kejahatan":

a. korupsi;

b. penyuapan;

c. penyelundupan barang;

d. penyelundupan tenaga kerja;

e. penyelundupan imigran;

f. perbankan;

g. narkotika;

h. psikotropika;

i. perdagangan budak, wanita dan anak;

j. perdagangan senjata gelap;

k. penculikan;

I. terorisme;

m. pencurian;

n. penggelapan;

o. penipuan,

Dalam rumusan tersebut disebutkan bahwa harta kekayaan yang berjumlah minimal $\mathrm{Rp} 500.000 .000,00$ (lima ratus juta rupiah) atau yang setara yang dihasilkan dari tindak pidana korupsi dan penyuapan (huruf a dan huruf b) sebagai perbuatan pencucian uang. Korupsi pada hakikatnya adalah salah satu bentuk kejahatan keuangan. Sebagai kejahatan keuangan (interprise Crimes) hampir pasti akan dilakukan pencucian uang atau paling tidak harus segera mungkin dilakukan pencucian uang. ${ }^{29}$ Antara korupsi dan penyuapan dengan pencucian uang terdapat satu rangkaian kejahatan, di mana korupsi dan penyuapan dapat dikatakan sebagai kejahatan asal (predicate offense) sedangkan pencucian uang merupakan kejahatan lanjutan (follow up Crime). ${ }^{30}$ Kejahatan dan hasil kejahatan tersebut dapat dikategorikan sebagai rangkaian korupsi yang sebaiknya dimasukkan dalam tindak pidana korupsi. Bahkan lebih jauh lagi, UNCAC merekomendasikan agar Tindak Pidana Pencucian Uang dimasukkan Ke dalam perundang-undangan tindak pidana korupsi, sebagaimana tercermin pada Pasal 14 dan Pasal 23 berikut ini:

\footnotetext{
${ }^{29}$ Lihat Yenti Garnasih. "Anti Pencucian Uang di Indonesia dan Kelemahan Implementasinya (suatu Tinjauan Awal)”Artikel dalam Jurnal Legislasi Indonesia Depkumham RI No.4 Vol.3 hlm. 135. ${ }^{30}$ ibid
} 


\section{Article 14. Measures to prevent money-laundering}

(Pasal 14. Tindakan-tindakan untuk Mencegah Pencucian Uang)

1. Each State Party shall (Setiap Negara Pihak wajib) :

(a) Membentuk rezim pengaturan dan pengawasan internal yang komprehensif untuk bank-bank dan lembaga-lembaga keuangan nonbank, termasuk orangorang pribadi dan badan-badan hukum yang memberikan jasa-jasa resmi atau tidak resmi untuk pengiriman uang atau nilai dan, bilamana tepat, badan-badan lain yang secara khusus rawan terhadap pencucian uang, di dalam kewenangannya, untuk menahan dan mendeteksi semua bentuk pencucian uang, rezim mana wajib menekankan persyaratan-persyaratan bagi nasabah dan, sebagaimana layaknya, identifikasi penerima hak, penyimpanan dokumen dan pelaporan transaksi-transaksi yang mencurigakan);

Article 23. Laundering of proceeds of Crime (Pasal 23. Pencucian Hasil-hasil Kejahatan)

1. Setiap Negara Pihak wajib mengambil, sesuai dengan prinsip-prinsip dasar hukum nasionalnya, tindakan-tindakan legislatif dan lainnya yang dianggap perlu untuk menetapkan sebagai kejahatan pidana, apabila dilakukan dengan sengaja:

(a) (i) Konversi atau transfer kekayaan, dengan mengetahui bahwa kekayaan tersebut adalah hasil-hasil kejahatan, untuk maksud menyembunyikan atau menyamarkan asal kekayaan yang tidak sah atau membantu orang siapa pun yang terlibat dalam pelaksanaan kejahatan asal untuk menghindari konsekuensi hukum dari tindakannya);

(ii) Penyembunyian atau penyamaran sifat, sumber, lokasi, pelepasan, perpindahan atau pemilikan yang sebenarnya dari atau hak-hak yang berkenaan dengan kekayaan, dengan mengetahui bahwa kekayaan tersebut adalah hasil-hasil kejahatan.

Penegasan Konvensi UNCAC dalam pasal 14 dan 23 tersebut merupakan isyarat bahwa kebijakan hukum pidana terkait tindak pidana pencucian uang akan lebih efektif jika dimasukkan sebagai tindak pidana korupsi yang merupakan rangkaian komprehensif dari kejahatan (comprehensive range of criminal offences). Penegasan Konvensi UNCAC mengenai perlunya tindak pidana pencucian uang dimasukkan sebagai tindak pidana korupsi, sesungguhnya bukan sesuatu hal yang baru, karena jauh sebelum Konvensi UNCAC dirumuskan, Barda Nawawi Arief telah merekomendasikan agar tindak pidana pencucian uang dimasukkan sebagai tindak pidana korupsi, yakni dalam Seminar Nasional "MENYONGSONG PEMBAHARUAN DAN PEM-BENTUKAN UNDANG-UNDANG PEMBERANTASAN KORUPSI, KOLUSI DAN NEPOTISME", di Baturraden, Purwokerto, 30 Januari 1999, dan dalam Seminar Nasional "Pemberantasan dan Penanggulangan Korupsi Dengan Sistem Pembuktian Terbalik", FH UNS, 10 Juli 2001. Menurutnya bahwa: ${ }^{31}$

dalam UU No. 3/1971 maupun UU No. 31/1999 hanya ada dua kelompok tindak pidana korupsi, yaitu :kelompok TP-K (Tindak pidana Korupsi) dan kelompok TP-BDK (Tindak Pidana yang Berhubungan Dengan Korupsi). Jadi belum ada kelompok ketiga, yang saya sebut dengan istilah "Tindak Pidana Setelah Korupsi" (disingkat "TP-SK"). Ke dalam kelompok ketiga inilah saya

\footnotetext{
${ }^{31}$ Barda Nawawi Arief, "Pencucian Uang dari Perspektif RUU Tindak Pidana Korupsi dalam Upaya Asset Rocovery" Makalah disampaikan pada Seminar yang diselenggarakan oleh Kejaksaan Agung, Jakarta, 15 Nopember 2007.hIm.6
} 
usulkan dimasukkannya tindak pidana pencucian uang (TPPU - Money Laundering).

\section{B.2. Kebijakan Formulasi Hukum Pidana dalam Penanggulangan Tindak Pidana Korupsi yang Akan Datang}

Kebijakan formulasi Hukum Pidana dalam rangka penanggulan tindak pidana korupsi yang akan datang sebenarnya telah diupayakan yaitu melalui penyusunan dalam RUU Pemberantasan Tindak Pidana Korupsi (Naskah bulan Agustus 2008) $)^{32}$.

Konsep RUU Pemberantasan Tindak Pidana Korupsi tersebut, merujuk pada Konvensi UNCAC 2003, hal mana ditegaskan dalam konsiderans yang menyatakan :"bahwa dengan telah diratifikasinya United Nations Convention Against Corruption, 2003 (Konvensi Perserikatan Bangsa-Bangsa Anti Korupsi2003) dengan Undang-Undang Nomor 7 Tahun 2006, maka Undang-Undang Nomor 31 Tahun 1999 tentang Pemberantasan Tindak Pidana Korupsi sebagaimana telah diubah dengan Undang-Undang Nomor 20 Tahun 2001 perlu disesuaikan dengan Konvensi Perserikatan Bangsa-Bangsa Anti Korupsi 2003 tersebut."

RUU Pemberantasan Tindak Pidana Korupsi memberikan pengertianpengertian atau penggunaan istilah-istilah mengenai beberapa hal tertentu dalam Bab I (ketentuan umum) sebagai berkut:

Pasal 1

Dalam Undang-Undang ini yang dimaksud dengan:

1. Korporasi adalah kumpulan orang dan/atau kekayaan yang terorganisasi baik merupakan badan hukum maupun bukan badan hukum.

2. Pejabat Publik adalah:

a. setiap orang yang memegang jabatan legislatif, yudikatif, atau eksekutif yang ditunjuk atau dipilih tetap atau sementara dibayar atau tidak dibayar terlepas dari senioritas orang itu;

b. setiap orang yang melaksanakan fungsi publik termasuk untuk kepentingan suatu instansi publik atau perusahaan publik atau suatu yang menyediakan pelayanan publik berdasarkan peraturan perundang-undangan;

c. setiap orang yang ditetapkan sebagai pejabat publik dalam peraturan perundangundangan.

3. Pejabat Publik Asing adalah:

a. setiap orang yang memegang jabatan eksekutif, legislatif, atau yudikatif suatu negara asing baik berdasarkan penunjukan atau pemilihan, termasuk semua tingkatan dan bagian pemerintahannya

b. setiap orang yang menjalankan fungsi publik untuk kepentingan suatu negara asing, termasuk instansi publik atau perusahaan publik asing; atau

c. setiap pejabat atau perwakilan organisasi publik internasional.

4. Pejabat Organisasi Internasional Publik adalah setiap pegawai sipil internasional atau setiap orang yang diberi kewenangan oleh organisasi tersebut untuk bertindak atas nama organisasi tersebut.

5. Kekayaan adalah aset bentuk apa pun, baik korporal atau nonkorporal, bergerak atau tidak bergerak, berwujud atau tidak berwujud, dan dokumen atau instrumen hukum yang membuktikan hak atau kepentingan atas aset tersebut.

6. Penyitaan adalah serangkaian tindakan penyidik untuk mengambil alih dan/atau menyimpan di bawah penguasaannya benda bergerak atau tidak bergerak,

${ }^{32}$ http://reformasihukum.org/file/peraturan/RUTipikor 
berwujud atau tidak berwujud untuk kepentingan penyidikan, penuntutan, dan peradilan.

7. Perampasan adalah pengambilalihan secara permanen atas kekayaan dengan putusan pengadilan atau badan berwenang yang lain.

8. Tindak Pidana Asal adalah setiap tindak pidana yang menimbulkan hasil tindak pidana yang menjadi obyek tindak pidana lain.

9. Hasil Tindak Pidana adalah setiap kekayaan yang diperoleh secara langsung atau tidak langsung dari suatu tindak pidana.

10. Hadiah atau Janji adalah segala bentuk apapun yang memberikan manfaat atau kenikmatan bagi yang menerima.

Pengertian-pengertian sebagaimana yang diatur dalam Bab I (ketentuan umum) tersebut di atas terkesan menyesuaikan dengan redaksi Konvensi UNCAC 2003 sebagai berikut:

Article 2. Use of terms (Penggunaan Istilah-istilah)

(a) "Pejabat publik" berarti: (i) setiap orang yang memegang jabatan legislatif, eksekutif, administratif, atau yudikatif dari suatu Negara Pihak, baik diangkat atau dipilih, baik tetap atau sementara, baik dibayar atau tidak dibayar, tanpa memperhatikan senioritas orang itu; (ii) setiap orang yang melaksanakan fungsi publik, termasuk untuk suatu instansi publik atau perusahaan publik, atau memberikan layanan umum, sebagaimana dimaksud dalam undang-undang nasional Negara Pihak dan sebagaimana berlaku di bidang hukum yang sesuai dari Negara Pihak tersebut; (iii) setiap orang yang dimaksud sebagai "pejabat publik" dalam undang-undang nasional Negara Pihak. Namun demikian, untuk tujuan upaya-upaya tertentu yang tercantum dalam bab II Konvensi ini, "pejabat publik" dapat berarti setiap orang yang melaksanakan fungsi publik atau menyediakan layanan umum sebagaimana dimaksud dalam undangundang nasional Negara Pihak dan sebagaimana berlaku di bidang hukum yang sesuai dari Negara Pihak tersebut;

(b) "Pejabat publik asing" berarti setiap orang yang memegang jabatan legislatif, eksekutif, administratif, atau yudikatif dari suatu negara asing, baik diangkat atau dipilih, dan setiap orang yang melaksanakan fungsi publik untuk suatu negara asing, termasuk untuk instansi publik atau perusahaan publik;

(c) "Pejabat organisasi internasional publik" berarti setiap pegawai sipil internasional atau setiap orang yang diberi kewenangan oleh organisasi tersebut untuk bertindak atas nama organisasi tersebut;

(d) "Kekayaan" berarti aset bentuk apa pun, baik korporal atau nonkorporal, bergerak atau tidak bergerak, berwujud atau tidak berwujud, dan dokumen atau instrumen hukum yang membuktikan hak atas atau kepentingan dalam aset tersebut;

(e) "Hasil-hasil kejahatan" berarti setiap kekayaan yang berasal dari atau diperoleh, secara langsung atau tidak langsung, melalui pelaksanaan suatu kejahatan;

(f) "Pembekuan" atau "penyitaan" berarti pelarangan sementara transfer, konversi, pelepasan atau pemindahan kekayaan, atau pengawasan sementara atau pengendalian kekayaan berdasarkan suatu perintah yang dikeluarkan oleh pengadilan atau badan berwenang lainnya;)

(g) "Perampasan" yang meliputi pengenaan denda bilamana dapat diberlakukan, berarti perampasan permanen atas kekayaan dengan perintah pengadilan atau badan berwenang lainnya;)

(h) "Kejahatan asal" berarti setiap kejahatan dengan mana hasil-hasil yang diperoleh dapat menjadi subyek dari suatu kejahatan. 
Pengertian atau penggunaan istilah khususnya mengenai istilah "pejabat Publik" sebagaimana tersebut di atas pada hakikatnya merupakan istilah yang janggal jika digunakan dalam istilah yuridis, karena dalam perundang-undangan di Indonesia istilah-istilah tersebut tidak dikenal. Berdasarkan perundang-undangan di Indonesia di kenal beberapa istilah yuridis, misalnya "Penyelenggara Negara" istilah yang terdapat Undang-Undang Nomor 28 Tahun 1999 Tentang Penyelenggaraan Negara yang Bersih dan Bebas KKN, "Pegawai Negeri" istilah yang terdapat dalam Undang-undang Nomor 31 Tahun 1999 jo Undang-undang Nomor 20 Tahun 2001 Tentang Pemberantasan Tindak Pidana Korupsi. Jadi istilah "Pejabat Publik" merupakan istilah umum dan bukan istilah yuridis, sehingga perlu disesuaikan dulu agar menjadi istilah yuridis. Selain penggunaan istilah-istilah tersebut di atas, Rumusan tindak pidana korupsi dalam RUU ini pun terkesan disesuaikan dengan redaksi dalam Konvensi UNCAC yang diatur dalam beberapa pasal berikut:

Pasal 2

(1) Setiap orang yang menjanjikan, menawarkan, atau memberikan secara langsung atau tidak langsung kepada Pejabat Publik suatu keuntungan yang tidak semestinya untuk kepentingan pejabat itu sendiri, orang lain, atau Korporasi, supaya pejabat tersebut berbuat atau tidak berbuat sesuatu dalam pelaksanaan tugas jabatannya

(2) Pejabat Publik yang meminta atau menerima secara langsung atau tidak langsung suatu keuntungan yang tidak semestinya untuk kepentingan pejabat itu sendiri, orang lain, atau Korporasi, supaya Pejabat Publik tersebut berbuat atau tidak berbuat sesuatu dalam pelaksanaan tugas jabatannya

Rumusan tindak pidana dalam Pasal 2 RUU pemberantasan Tindak Pidana korupsi di atas merupakan penyesuaian redaksi dalam Pasal 15 Konvensi UNCAC yang redaksi sebagai berikut:

(a) Janji, penawaran atau pemberian kepada pejabat publik, secara langsung atau tidak langsung, manfaat yang tidak semestinya, untuk pejabat publik dalam kapasitas tugas resminya atau orang atau badan lain agar pejabat itu bertindak atau berhenti bertindak dalam pelaksanaan tugas-tugas resmi mereka;

(b) Permintaan atau penerimaan oleh pejabat publik, secara langsung atau tidak langsung, manfaat yang tidak semestinya, untuk pejabat publik tersebut dalam kapasitas tugas resminya atau orang atau badan lain agar pejabat itu bertindak atau berhenti bertindak dalam pelaksanaan tugas-tugas resmi).

Rumusan tindak pidana korupsi sebagaimana diuraikan di atas, tidak ada satu pun rumusan tindak pidana korupsi yang menitikberatkan pada unsur "merugikan keuangan atau perekonomian negara". Hal ini berbeda dengan rumusan tindak pidana korupsi yang terdapat dalam Undang-undang Nomor 31 Tahun 1999 jo. Undang-undang Nomor 20 Tahun 2001 yang saat ini masih berlaku. Penekanan terhadap unsur "merugikan keuangan atau perekonomian negara" dalam rumusan tindak pidana korupsi sangat penting, karena apabila terjadi kerugian terhadap "keuangan atau perekonomian negara" maka negara akan mengalami kesulitan atau mengakibatkan terhambatnya negara dalam memenuhi pelayanan terhadap kepentingan publik, yang berarti juga negara tidak dapat menjalankan kewajibannya dalam mensejahterakan masyarakat, yang merupakan kewajiban konstitusionalnya. Undang-undang Anti Korupsi di Korea, dalam merumuskan tindak pidana korupsi lebih menekankan pada unsur "kerugian atau kerusakan pada hak milik negara" ("The act of causing damages to the property of any public Agency"), yaitu dalam 
Pasal 2 ayat (3) Undang-undang Nomor 6494, 24 Juli, 2001 ${ }^{33}$ yang menegaskan bahwa:

(a) Tindakan para pegawai publik yang mencari keuntungan untuk dirinya sendiri atau untuk pihak ketiga dengan menyalahgunakan kedudukan atau kewenangannya atau melanggar undang-undang dan peraturan pelaksana dalam hubungannya dengan tugasnya (kewajibannya); dan

(b) Tindakan yang menyebabkan kerusakan terhadap hak milik Negara (public agency) dengan melanggar undang-undang dan peraturan pelaksana, dengan cara menggunakan anggaran pegawai yang terkait, memperoleh, mengelola, atau menempatkan hak milik pegawai terkait, atau mengikatkan atau melaksanakan kontrak di mana pegawai yang terkait sebagai salah satu pihak).

Persoalan lain dalam RUU ini adalah, rumusan tindak pidana tampaknya berorientasi pada konvensi UNCAC, sehingga terkesan melepaspisahkan Undangundang khusus dengan KUHP sebagai sistem induk, dan terkesan mengabaikan kebijakan kriminalisasi yang sudah dilakukan. Hal ini berbeda dengan rumusan Undang-undang Anti Korupsi Korea Nomor 6494, 24 Juli, 2001, di mana undang-undang khusus tetap mendasarkan tindak pidana korupsi pada KUHP sebagai sistem induk, hal mana dikatakan dalam Pasal 31 ayat (1) Undang-undang anti korupsi Korea yang mengatur mengenai Filing Adjudication, menyatakan bahwa "where a person suspected of committing the act ......... falls under Articles 129 through 133 and 355 through 357 of the Criminal Act" "Apabila seseorang yang diduga melakukan tindakan korupsi.......berdasar Pasal 129, Pasal 133, Pasal 355 dan Pasal 357 KUHP"), dan dalam Pasal 129 ayat (1) KUHP Korea, misalnya dikatakan bahwa "A public official or an arbitrator who receives, demands or promises to accept a bribe in connection with his duties, ("seorang pejabat publik meminta, menjanjikan atau menerima suap yang berkaitan dengan tugastugasnya"). Ini menunjukkan bahwa undang-undang khusus mengenai tindak pidana korupsi di Korea, tetap mendasarkan pada rumusan tindak pidana korupsi yang diatur dalam KUHP, atau setidak-tidaknya menunjukkan bahwa undangundang khusus mengenai tindak pidana korupsi yang berlaku tidak mencabut KUHP sebagai sistem induk. Penekanan mengenai rumusan tindak pidana korupsi yang ditunjukkan dalam undang-undang anti korupsi di Korea sebagaimana diuraikan di atas, memiliki persamaan dengan pengertian/batasan yuridis mengenai petugas badan publik sebagai subyek hukum tindak pidana korupsi yang diatur dalam undang-undang anti korupsi Malaysia, di mana dalam Pasal 2 Undang-undang Nomor 575 Tahun 1997 di sebutkan bahwa "Petugas dari badan publik berarti setiap orang yang merupakan anggota, perwira, karyawan, atau pembantu badan publik, dan termasuk anggota pemerintahan, anggota parlemen, anggota Dewan Legislatif Negara, seorang hakim dari Pengadilan Tinggi, Pengadilan Federal, dan setiap orang yang menerima imbalan apa pun dari dana masyarakat, termasuk badan publik adalah sebuah perusahaan tunggal". ( yang dimaksud dengan tindak pidana sebagaimana yang dicantumkan dalam pasal 2 tersebut adalah tindak pidana sebagaimana dimaksud dalam Pasal 161,162,163,164,165,213,214 atau 215 KUHP).

Pasal 161 KUHP Malaysia (Law of Malaysia Act 574 Penal Code) ${ }^{34}$ sebagaiamana disebutkan dalam Pasal 2 Undang-undang anti korupsi Malaysia di atas menyatakan bahwa "Setiap orang, atau pegawai negeri, menerima atau

\footnotetext{
${ }^{33}$ http://unpan1.un.org/intradoc/groups/public/documents/APCITY/UNPAN019095

${ }^{34} \mathrm{http}: / /$ www.agc.gov.my/agc/Akta/Vol. 12/Act 574
} 
memperoleh gratifikasi, hadiah untuk diri sendiri atau orang lain agar melakukan tindakan dalam jabatan atau memberikan layanan apapun dengan menguntungkan orang lain, pemerintah, anggota kabinet atau Parlemen, Dewan Eksekutif Negara, Majelis Legislatif atau pegawai negeri”. Selain persoalan-persoalan sebagaimana diuraikan di atas, RUU Pemberantasan Tindak Pidana Korupsi ini juga masih mempunyai persoalan yang hampir sama dengan Undang-undang Nomor 31 Tahun 1999 jo Undang-undang Nomor 20 Tahun 2001 Tentang Pemberantasan Tindak Pidana Korupsi, yaitu:

a. tidak ada penegasan "korporasi" sebagai subjek delik

b. tidak ada ketentuan khusus mengenai percobaan, pembantuan, dan permukatan jahat;

c. tidak ada penentuan kualifikasi delik (sebagai "kejahatan" atau "pelanggaran").

Sebagai langkah kebijakan hukum pidana dalam penanggulangan tindak pidana korupsi, Konsep KUHP 2006-2008, merumuskan tindak pidana korupsi dalam Bab XXXII mengenai tindak pidana korupsi, sebagai mana yang diatur dalam Pasal 680, Pasal 681, Pasal 682 (lingkup suap). Pasal 683,Pasal 684, Pasal 686, Pasal 687 (Lingkup Penyalahgunaan wewenang yang Merugikan Keuangan Negara).Pada bagian lain kategori sebagai tindak pidana korupsi, diatur pula dalam Konsep KUHP 2006-2008 mengenai Tindak Pidana Jabatan yang diatur dalam BAB XXX Pasal 655, Pasal 658,Pasal 659, Pasal 660, Pasal 662, Pasal 663, Pasal 664. Pada inti hakikatnya perumusan tindak pidana korupsi dengan ruang lingkup yang dirumuskan dalam Konsep KUHP 2006-2008 tersebut sudah cukup memberikan daya tangkal atau penanggulangan terhadap tindak pidana korupsi terutama bagi para White collar Crime yang melibatkan pejabat negara, termasuk di dalamnya penegak hukum, sebagaimana yang digariskan dalam Pasal 660 Konsep KUHP. Bahkan dalam hal menerima hadiah atau gratifikasi "dapat" dikenakan sebelum atau sesudah perbuatan itu dilakukan, hal tersebut ditegaskan dalam Pasal 659 Konsep KUHP, dengan rumusan :

"menerima hadiah, janji atau gratifikasi padahal diketahui atau patut diduga bahwa hadiah, janji, atau gratifikasi tersebut diberikan untuk menggerakkan agar melakukan atau tidak melakukan sesuatu dalam jabatannya yang bertentangan dengan kewajibannya; atau menerima hadiah, janji, atau gratifikasi padahal diketahui atau patut diduga bahwa hadiah, janji, atau gratifikasi tersebut diberikan sebagai akibat atau disebabkan karena telah melakukan atau tidak melakukan sesuatu dalam sauatu jabatannya yang bertentangan dengan kewajibannya".

Daya jangkau Pasal 659 Konsep KUHP 2006-2008 tersebut sesungguhnya lebih komprehensif di bandingkan rumusan tindak pidana korupsi dalam lingkup "gratifikasi" yang dirumuskan dalam Pasal 8 Undang-undang anti korupsi Korea dan Pasal 10 Undang-undang anti korupsi Malaysia, yang terkesan hanya memiliki daya jangkau pada sebelum perbuatan dilakukan. Pasal 8 ayat (2) angka 1 dan 2 undang -undang anti Korupsi Korea Nomor $6494^{35}$ yang menyatakan bahwa :

1. Berbagai hal yang melarang dan membatasi pegawai pemerintah dari menerima hadiah, uang dan hal lainnya, dari siapa pun yang berhubungan dengan tugasnya;

2. Berbagai hal yang melarang dan membatasi pegawai pemerintah dari mempengaruhi masalah kehidupan pribadi, engaging in outside financial interests, memperkenalkan hubungan yang tidak sah atau memohon kebaikan semua dengan menggunakan posisinya.

\footnotetext{
${ }^{35}$ http://unpan1.un.org/intradoc/groups/public/documents/APCITY/UNPAN019095.
} 
Hal yang hampir sama juga sebagaimana dituangkan dalam Pasal 10 Undang-undang Malaysia No.575 Tahun1997 Tentang Anti Korupsi ${ }^{36}$ yang menegaskan bahwa:

setiap orang yang dengan dirinya sendiri, atau bersama orang lain-)

(a) meminta atau menerima atau setuju untuk menerima untuk dirinya sendiri atau untuk orang lain; atau )

(b) memberikan janji atau menawarkan untuk setiap orang baik untuk kepentingan diri sendiri atau orang lain, setiap gratifikasi sebagai ajakan atau hadiah)

(aa) setiap orang yang melakukan atau untuk melakukan tindakan apapun sehubungan dengan materi atau transaksi aktual atau yang diusulkan atau yang mungkin terjadi; atau

(bb) setiap petugas badan publik yang melakukan tindakan apapun sehubungan dengan materi atau transaksi, aktual atau yang diusulkan atau yang mungkin terjadi, di mana badan publik yang bersangkutan bersalah atas suatu tindak pidana.

Memperhatikan rumusan yang telah diatur dalam Konsep KUHP 2006-2008 sebagaimana diuraikan di atas, sebaiknya menjadikan Kosep KUHP 2006-2008 sebagai Kebijakan hukum pidana bagi pemberantasan tindak pidana korupsi yang akan datang. Dijadikannya Konsep KUHP 2006-2008 sebagai kebijakan hukum pidana dalam penanggulangan tindak pidana korupsi yang akan datang, diharapkan tidak terjadi diskrepansi dengan aspirasi masyarakat, terutama dalam hal menjawab kebutuhan hukum masyarakat dalam mengatasi tindak pidana korupsi, di sisi lain bahwa Konsep KUHP 2006-2008 merupakan hasil pemikiran-pemikiran hukum yang didasarkan pada nilai-nilai budaya bangsa (yang tentunya berbeda dengan kondisi KUHP yang saat ini berlaku)

\section{PENUTUP}

\section{C.1. Kesimpulan}

Secara keseluruhan, kesimpulan yang diperoleh dari penelitian dan pembahasan terhadap 2 (dua) masalah pokok di atas adalah sebagai berikut:

1.Kebijakan formulasi hukum pidana khususnya mengenai formulasi tindak pidana korupsi saat ini, memiliki sejumlah kelemahan yang mendasar, sebagi berikut:

a. kebijakan hukum pidana dalam hal tindak pidana korupsi yang berlaku saat ini, tindak mencantumkan kualifikasi delik apakah sebagai "pelanggaran" atau "kejahatan".

b. kebijakan Hukum pidana dalam hal tindak pidana korupsi saat ini tidak memberikan pengertian atau batasan-batasan yuridis mengenai "permufakatan jahat", "tindak pidana dalam hal pembantuan atau pembatu" (medeplichtige) dan "pengulangan tindak pidana" (recidive) .

b. kebijakan hukum pidana dalam hal pemberantasan tidak pidana korupsi, masih tersebar di beberapa perundang-undangan dan menggunakan sanksi berdasarkan undang-undang yang berbeda, hal ini dapat menimbulkan persoalan terutama dalam aspek keadilan.

2. mencermati kelemahan-kelemahan yang terdapat dalam kebijakan hukum pidana mengenai tindak pidana korupsi saat ini, serta kelemahan-kelemahan yang terdapat dalam Rancangan Undang-Undang Tentang Pemberantasan Tindak Pidana Korupsi yang disusun oleh pemerintah (Naskah bulan

\footnotetext{
${ }^{36}$ http://politiku.xpart e.com/aca 1997.
} 
Agustus 2008), maka sebaiknya dilakukan pembaharuan terhadap kebijakan hukum pidana mengenai tindak pidana korupsi untuk yang akan datang, dengan memperhatikan hal-hal sebagai berikut:

a. rumusan tindak pidana korupsi tetap menekankan pada unsur "merugikan keuangan atau perekonomian negara". memberikan pengertian yuridis mengenai "Permufakatan jahat", serta "pengulangan tindak pidana" (recedive).

b. menjadikan tindak pidana pencucian uang sebagi tindak pidana korupsi.

c. mencantumkan pemberatan pidana atau pemidanaan untuk tindak pidana korupsi khususnya pada lingkup "suap" dan "pemerasan dalam jabatan" yang dilakukan oleh penegak hukum terhadap perkara-perkara hukum yang sedang diperiksa.

Oleh Karena itu, maka Konsep KUHP 2006-2008 merupakan kebijakan hukum pidana yang tepat dalam penanggulangan tindak pidana korupsi yang akan datang, di mana perumusan Konsep KUHP 2006-2008 merupakan hasil pemikiran hukum yang berakar dari nilai-nilai budaya bangsa Indonesia, dalam menjawab kebutuhan hukum sesuai dengan aspirasi masyarakat dalam memberantas korupsi, dan sesuai dengan apa yang dimaksud dengan penal policy.

\section{C.2. Saran}

Untuk menciptakan perlindungan dan kesejahteraan masyarakat tersebut, maka upaya yang dilakukan dalam hal merumuskan kebijakan hukum pidana dalam penanggulangan tindak pidana korupsi sebagaimana yang dituangkan dalam Konsep KUHP 2006-2008 dirasakan sangat memadai, hal ini didasarkan atas ruang lingkup mengenai tindak pidana korupsi yang dirumuskan cukup komprehensif, jika dibandingkan dengan perumusan tindak pidana korupsi yang dilakukan di Korea berdasarkan Undang-undang anti korupsi Nomor 6494, 24 Juli, 2001, dan sebagaimana yang dirumuskan dalam undang-undang anti korupsi Malaysia, yaitu dalam Undang-undang Nomor 575 Tahun 1997 Tentang Anti Korupsi, di samping itu Konsep KUHP 2006-2008 dalam merumuskan mengenai tindak pidana korupsi dirasakan lebih baik dari perumusan tindak pidana korupsi sebagaimana yang dituangkan dalam Rancangan Undang-undang Tentang Pemberantasan Tindak Pidana Korupsi yang disusun oleh pemerintah, selain itu, bahwa Konsep KUHP 2006-2008 merupakan hasil pemikiran hukum yang berakar dari nilai-nilai budaya bangsa Indonesia, dalam menjawab kebutuhan hukum sesuai dengan aspirasi masyarakat dalam memberantas korupsi, dan sesuai dengan apa yang dimaksud dengan penal policy. sehingga diharapkan lebih efektif dalam penanggulangan tindak pidana korupsi, baik secara pencegahan umum maupun khusus. Lebih jauh dari itu bahwa Konsep KUHP 2006-2008 tidak terdapat diskrepansi dengan aspirasi masyarakat, serta responsif terhadap kebutuhan sosial dalam pemberantasan tindak pidana korupsi di Indonesia. 


\section{Buku Teks}

\section{Daftar Pustaka}

Asikin, Zainal \& Amirudin, 2004, Pengantar Penelitian Hukum, Jakarta, Radja Grafindo Persada.

Atmasasmita, Romli.2004, Sekitar Masalah Korupsi, Aspek Nasional dan Aspek Internasional, Bandung, Mandar Maju.

Hamzah, Andi.2008, Asas-asas Hukum Pidana (edisi revisi) Jakarta, Rineka Cipta.

Hanitijo Soemitro, Ronny. 1982, Metodologi Penelitian Hukum, Jakarta, Ghalia Indonesia,

Hartono, Sunaryati. 1994, Penelitian Hukum Di Indonesia Pada Akhir Abad ke-20, Bandung, Alumni.

Moeljatno.1999, Kitab Undang-Undang Hukum Pidana (cetakan kedua puluh), Jakarta, Bumi Aksara.

2000, Asas-Asas Hukum Pidana, Jakarta, Rineka Cipta.

Muladi.2002, Lembaga Pidana Bersyarat, Bandung, Alumni.

Muladi dan Nawawi Arief, Barda. 1992, Bunga Rampai Hukum Pidana, Bandung, Alumni.

Alumni.

1998, Teori-teori dan Kebijakan Pidana, Bandung,

Nawawi Arief, Barda.2008, Masalah Penegakan Hukum dan Kebijakan Hukum Pidana dalam Penanggulangan Kejahatan, Jakarta, Kencana. .2008, Bunga Rampai Kebijakan Hukum Pidana, Perkembangan Penyusunan Konsep KUHP Baru, Jakarta, Kencana.

.2008, Perbandingan Hukum Pidana,Jakarta, RadjaGrafindo Persada.

2008, Sari Kuliah Hukum Pidana Lanjut, Semarang, Badan Perbit Undip.

.2008, RUU KUHP Baru Sebuah Restrukturisasi/Rekonstruksi

Sistem Hukum Pidana Indonesia, semarang, Badan Penerbit Undip.

2009, Tujuan dan Pedoman Pemidanaan, Semarang, Badan Penerbit Undip.

2009, Perkembangan Sistem Pemidanaan di Indonesia, Semarang, Badan Penerbit Undip.

Serikat Putra Jaya.2008, Beberapa Pemikiran ke Arah Pengembangan Hukum Pidana, Bandung, Citra Aditya Bakti.

Soekanto, Soerjono. 1986, Pengantar Penelitian Hukum, Jakarta, UI-Press. 2002, Pokok-pokok Sosiologi Hukum, Jakarta, RadjaGrafindo

Persada.

Sudarto.1977, Hukum dan Hukum Pidana, Bandung, Alumni.

\section{Jurnal IImiah}


Garnasih, Yenti.2006, "Anti Pencucian Uang di Indonesia dan Kelemahan dalam Implementasinya", Jurnal Legislasi Indonesia Depkumham RI, No. 4 Vol. 3.

\section{Makalah}

Nawawi Arief, Barda, "Pencucian Uang dari Perspektif RUU Tindak Pidana dalam Upaya Asset Rocovery" Makalah disampaikan pada Seminar yang diselenggarakan oleh Kejaksaan Agung, Jakarta, 15 Nopember 2007.

Supandji, Hendarman, "Peningkatan Pencegahan Tindak Pidana Korupsi dalam Pelaksanaan Tugas Kejaksaan", Makalah disampaikan dalam Kuliah Umum di Undip Semarang, tanggal 27 Februari 2009.

\section{Undang-undang}

Undang-undang Dasar Negara Republik Indonesia 1945.

Peraturan Penguasa Militer Nomor PRT/PM/06/1957 Tentang Pemberantasan Korupsi

Undang-undang Nomor 3 Tahun 1971 Tentang Pemberantasan Tindak Pidana Korupsi

Law of Malaysia Act 575 Anti-Corruption Act 1997

Undang-undang Nomor 10 Tahun 1998 Tentang Perbankan

Undang-Undang Nomor 28 Tahun 1999 Tentang Penyelenggaraan Negara yang Bersih dan Bebas KKN.

Undang-undang Nomor 31 Tahun 1999 Tentang Pemberantasan Tindak Pidana Korupsi.

Undang-Undang Nomor 16 Tahun 2000 Tentang Tentang Perubahan Kedua Atas Undang-Undang Nomor 6 Tahun 1983 Tentang Ketentuan Umum dan Tata Cara Perpajakan

Undang-undang Nomor 20 Tahun 2001 Tentang Pemberantasan Tindak Pidana Korupsi.

Undang-Undang Anti Korupsi Korea, Nomor 6494, 24 Juli, 2001

United Nations Convention Againts Corruption (UNCAC) 2003

United Nations Convention Againts Corruption (UNCAC) 2003 (terjemahan)

Undang-Undang Nomor 28 Tahun 2007 Tentang Perubahan Ketiga Atas UndangUndang Nomor 6 Tahun 1983 Tentang Ketentuan Umum dan Tata Cara Perpajakan

KUHP Malaysia (law of Malaysia Act 574 Penal Code)

KUHP Korea (The Criminal Code of Rebublic of Korea)

Konsep KUHP 2006

Konsep KUHP 2008

RUU Pemberantasan Tindak Pidana Korupsi 